\title{
EDUKASI PELABELAN KEMASAN PRODUK BAGI KARYAWAN TOKO RITEL MODERN DI KOTA PALEMBANG
}

\author{
A.D. Murtado'1), Alhanannasiri' \\ 1)Program Studi Ilmu dan Teknologi Pangan, Fakultas Pertanian, Universitas Muhammadiyah Palembang, Palembang, \\ Sumatera Selatan, Indonesia \\ Corresponding author : A.D Murtado \\ E-mail : murtado.asyari@yahoo.com
}

Diterima 06 November 2021, Direvisi 27 November 2021, Disetujui 28 November 2021

\begin{abstract}
ABSTRAK
Tahun 2018, di Palembang banyak berdiri toko ritel modern hususnya yang berada di bawah koperasi Syariah 212. Ada 20 toko yang berdiri pada tahun tersebut dan tersebar di dalam kota Palembang dan beberapa toko di luar kota Palembang. Hal ini tentu dibutuhkan pekerja layanan yang memahami bagaimana pengelolaan barang ritel hususnya pelabelan kemasan produk pangan yang sesuai dengan peraturan yang berlaku. Kurangnya pemahaman dari pekerja layanan mengakibatkan banyaknya keluhan konsumen. Tentu ini sangat merugikan baik pihak pemilik toko maupun konsumennya. Kegiatan bertujuan untuk meningkatkan pemahaman para pengelola ritel modern terhadap pelabelan pada kemasan produk. Kegiatan edukasi diikuti oleh para pengelola toko yang terdiri dari pelayan, kasir, supervisor dan kepala toko ritel modern 212 yang ada di kota Palembang dan sekitarnya. Kegiatan dilakukan dengan metode ceramah, diskusi dan praktek di toko ritel. Materi yang diberikan meliputi seluruh informasi yang terdapat dalam kemasan produk pangan, sesuai dengan peraturan badan pengawas obat dan makanan nomor 31 tahun 2018 tentang label pangan olahan. Pengetahuan peserta meningkat secara signifikan setelah diberikan pembelajaran.
\end{abstract}

Kata kunci: edukasi; pelebelan; ritel

\begin{abstract}
In 2018, there were many modern retail stores in Palembang, especially those under the Sharia 212 cooperative. There were 20 stores that were established that year and spread out in Palembang city and several shops outside Palembang city. This of course requires service workers who understand how to manage retail goods, especially labeling food product packaging in accordance with applicable regulations. Lack of understanding from service workers resulted in many consumer complaints. Of course this is very detrimental to both the shop owner and consumers. The activity aims to increase the understanding of modern retail managers on labeling on product packaging. Educational activities were followed by store managers consisting of waiters, cashiers, supervisors and heads of 212 modern retail stores in the city of Palembang and its surroundings. Activities are carried out using lecture, discussion and practice methods in retail stores. The material provided includes all information contained in food product packaging, in accordance with the regulation of the drug and food regulatory agency number 31 of 2018 concerning processed food labels. The knowledge of the participants increased significantly after being given the lesson.
\end{abstract}

Keywords: education; labeling; retail

\section{PENDAHULUAN}

Tahun 2018, di Palembang banyak berdiri toko ritel modern hususnya yang berada dibawah koperasi Syariah 212. Ada 20 toko yang berdiri pada tahun tersebut dan tersebar di dalam kota Palembang dan beberapa toko berada di luar kota Palembang. Pada waktu yang bersamaan banyak dibutuhkan tenaga kerja pengelolaan toko dari mulai pelayan harian, kasir, pengawas dan kepala. Mereka dituntut untuk bukan saja melayani dengan baik tetapi juga dituntut untuk mengetahui dan memahami terkait seluruh informasi yang ada pada kemasan, sesuai peraturan Badan Pengawas Obat dan Makanan no.31 tahun 2018 tentang kemasan pangan.

Label pangan adalah setiap keterangan mengenai pangan yang berbentuk gambar, tulisan, kombinasi keduanya, atau bentuk lain yang disertakan pada pangan, dimasukkan ke dalam, ditempelkan pada, atau merupakan bagian kemasan pangan (UU RI No. 7 tahun 1996). Dalam hal ini masyarakat harus dilindungi dari penggunaan kemasan pangan yang tidak memenuhi persyaratan keamanan pangan (BPOM, 2019). 
Penataan letak barang-barang itu tidak semata-mata didasarkan pada aspek dekoratif, melainkan juga faktor sifat barang, kebutuhan dan kebiasaan berbelanja pengunjung. Salah satu fungsi dari pengaturan tata letak toko adalah memberikan ruang yang tepat untuk tampilan, pencobaan produk, dan pemeriksaan. Tata letak harus dapat menentukan ruangruang yang digunakan untuk menempatkan produk di masing-masing departemen di lokasi terbaik sesuai dengan kebutuhan penjualan departemen masing-masing. Pengaturan yang efektif menempatkan barang dagangan di lokasi di mana ia menerima lebih atau kurang tampilan secara otomatis, memberikan ruang yang memadai untuk pemeriksaan, dan menempatkan peralatan layanan untuk membantu pengendalian arus lalu lintas yang melalui tempat penjualan (Aruman, 2014).

Beberapa pengetahuan penting yang harus dikuasai oleh para pengelola toko terkait pelabelan adalah nama produk, daftar bahan yang digunakan, berat bersih dan isi bersih, nama dan alamat pihak yang memproduksi atau yang mengimpor, ketentuan halal, tanggal dan kode produksi, keterangan kadaluarsa, nomor izin edar dll serta model pemajangan dan penyusunan di rak rak toko dengan konsep fifo. Kurangnya pemahaman terhadap peraturan tersebut berakibat banyaknya keluhan konsumen kepada toko. Hal ini tentu berakibat buruk dan merugikan. Bukan saja merugikan toko tetapi juga merugikan konsumen. Oleh karena itu dibutuhkan eduksi dalam rangka peningkatan pemahamannya hususnya untuk para pengelola toko. Diharapkan melalui kegiatan ini para pengelola mampu melakukan kerja bukan saja melayani konsumen dengan baik tetapi juga mengetahui dan mampu melaksanakan pengelolaan barang barang sesuai dengan aturan yang berlaku.

\section{METODE}

\section{Tempat dan Waktu}

Tempat pelaksanaan kegiatan ini adalah di Jakabaring kota Palembang pada tanggal 1819 September 2021

\section{Khalayak sasaran}

Kegiatan diikuti oleh para pengelola toko yang terdiri dari pelayan, kasir, supervisor dan kepala toko dari 20 toko ritel modern 212 yang ada di kota Palembang dan sekitarnya. Selain para pengelola, acara dihadiri juga oleh beberapa orang pengurus koperasi yang menaunginya.

\section{Metode Pengabdian}

Kegiata ini dilakukan dengan metode ceramah, diskusi dan praktek.

\section{Indikator Keberhasilan}

Untuk mengukur tingkat keberhasilan kegiatan ini adalah dimana karyawan toko memiliki pemahaman terhadap peraturan tentang pelabelan pada kemasan produk pangan dan non pangan serta mampu mempraktekkan secara mandiri. Seluruh informasi yang tertera pada kemasan dipahami secara benar oleh peserta kegiatan.

\section{Metode Evaluasi}

Untuk mengukur tingkat keberhasilan dari kegiatan ini, dilakukan pre-test dan post-test. Pre-test bertujuan untuk mengukur kompetensi awal peserta sebelum menerima seluruh materi pembelajaran. Post- test dilakukan untuk mengukur tingkat serapan peserta terhadap materi pembelajaran. Diharapkan setelah kegiatan ini ada peningkatan pemahaman terkait pelabelan pada kemasan pangan dan non pangamn sarta mampu mempraktekkannya dalam pengelolaan produk di dalam gudang dan di dalam toko.

\section{HASIL DAN PEMBAHASAN Pretest}

Hasil pretest yang dilakukan terhadap peserta menunjukkan hasil bahwa tingkat pemahaman terhadap peraturan terkait pelabelan produk pada kemasan adalah $30 \%$ $45 \%$. Ini menunjukkan bahwa pengetahuan mereka masih sangat rendah. Sehingga wajar jika sering terjadi komplain konsumen terhadap produk yang dibelinya.

\section{Ceramah dan Diskusi}

Materi yang disampaikan meliputi seluruh informasi yang terdapat dalam kemasan produk pangan, sesuai dengan peraturan badan pengawas obat dan makanan nomor 31 tahun 2018 tentang label pada kemasan pangan olahan, yang meliputi nama produk, daftar bahan yang digunakan, berat bersih dan isi bersih, nama dan alamat pihak yang memproduksi atau yang mengimpor, ketentuan halal, tanggal dan kode produksi, keterangan kadaluarsa, nomor izin edar dll. Materi disampaikan secara terinci dan jelas serta sistimatis sesuai dengan isi peraturan tersebut. Peserta terlebih dahulu dikenalkan apa itu kemasan dan apa fungsinya serta informasi apa saja yang harus ada pada kemasan. Di sela sela ceramah diselingi dengan beberapa pertanyaan dari peserta. Situasi ini membuat kelas tampak lebih aktif dan dinamis (Gambar 1 dan 2) 


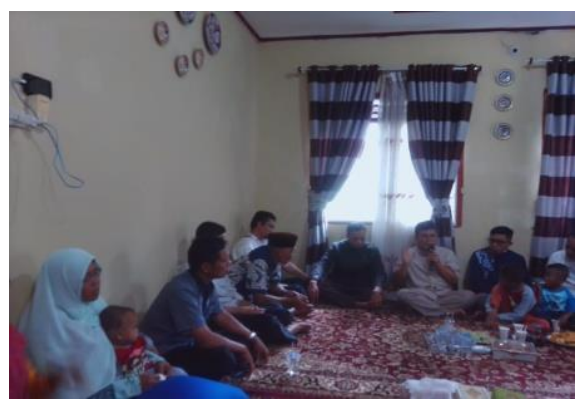

Gambar 1. Kegiatan Ceramah

(sumber: doc. pribadi, 2021)

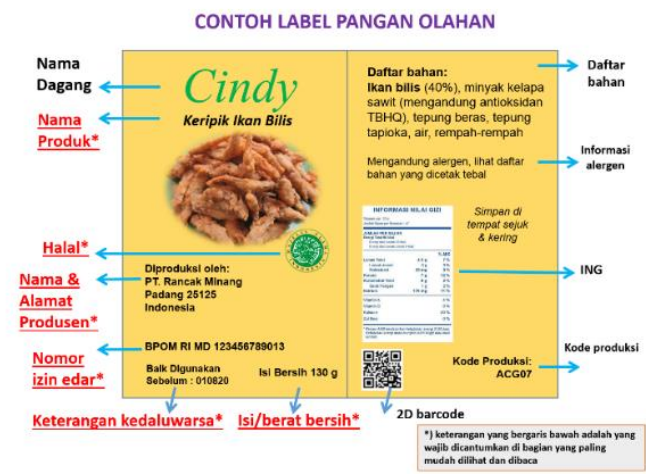

Gambar 2. Materi Ceramah

(sumber: stanaumkm, 2021)

\section{Post-test}

Setelah seluruh materi di sampaikan secara tuntas selanjutnya dilakukan post-test. Materi post-test adalah juga materi yang diberikan saat pre-test. Hasil dari post-test menunjukkan bahwa tingkat pemahaman peserta setelah proses pembelajar terkait peraturan badan pengawas obat dan makanan nomor 31 tahun 2018 tentang pelabelan pangan olahan sesuai pedoman standarisasi pangan olahan Badan Pengawas Obat dan Makanan, 2019. Seluruh materi yang disampaikan hampir seluruhnya dipahami. Skor yang diperoleh antara $86 \%$ sampai $97 \%$

\section{Praktek}

Tingkat pemahaman peserta terhadap seluruh materi yang disampaikan diaplikasikan melalui kegiatan prtaktek. Peserta dimintkan untuk menjelaskan informasi yang terdapat pada kemasan serta bagaimana menyusun barang di rak rak toko dan di dalam gudang sesuai dengan prinsif FIFO. Tahap ini mampu memperdalam dan memperjelas pemahaman dari materi yang disampaikan dalam kelas. Peserta mampu mempraktekkan hasil pembelajaran. Label yang terdapat pada kemasan menjadi perhatian saat penyusunan barang dan juga melaksanakan prisnsif FIFO di rak rak toko. (gambar 3, 4 dan 5)

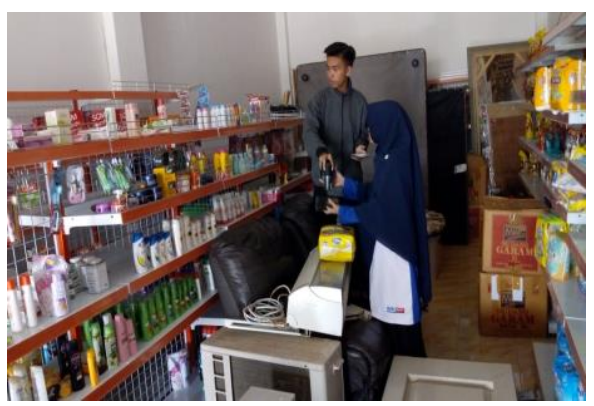

Gambar 3. Peserta menyusun barang berdasarkan jenis produknya (sumber: doc. pribadi, 2021)

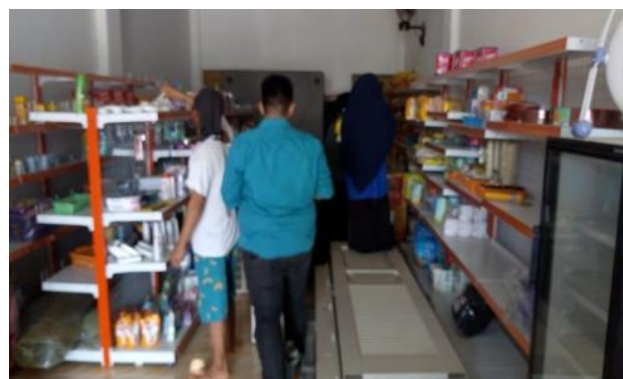

Gambar 4. Peserta memeriksa

kelengkapan pelebelan pada kemasan (sumber: doc. pribadi, 2021)

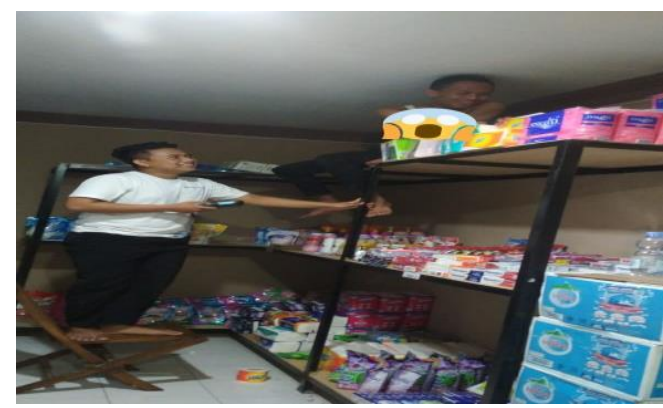

Gambar 5. Peserta menyusun barang berdasarkan kedaluarsa (sumber: doc. pribadi, 2021)

\section{SIMPULAN DAN SARAN}

Pembelajaran bagi para pengelola toko ritel modern adalah sangat dibutuhkan untuk peningkatan kompetensi karyawan dalam melaksanakan tugasnya. Pembelajaran juga dapat memberikan kenyamanan pada konsumen. Karyawan bukan saja dituntut untuk memberikan pelayanan yang ramah akan tetapi juga mampu memberikan informasi yang dimintakan oleh konsumen terkait produk yang dibutuhkannya. Melalui kegiatan pembelajaran ini terbukti bahwa ada peningkatan pemahaman peserta terhadap materi yang disampaikan dan mampu mempraktekkannya secara mandiri.

\section{UCAPAN TERIMAKASIH}

Disampaikan ucapan terimakasih kepada para pengurus koperasi dan komunitas 212 mart yang telah memberikan kontribusi atas 
terselengaranya kegiatan pengabdian ini. Ucapan terimaksih juga disampaikan untuk ketua LPPM Universitas Muhammadiyah Palembang yang telah mempasilitasi kegiatan ini.

\section{DAFTAR RUJUKAN}

Adiwijaya, M. (2010). 8 jurus jitu mengelola bisnis ritel ala ndonesia. 142.

Badan Pengawas Obat dan Makanan Republik ndonesia. (2019a). Pedoman mplementasi Pelabelan Pangan Olahan (1st ed.). Direktorat standarisasi pangan olahan.

Badan Pengawas Obat dan Makanan Republik ndonesia. (2019b). Peraturan Badan Pengawas Obat dan Makanan Nomor 20 Tahun 2019 tentang Kemasan Pangan. Badan Pengawas Obat Dan Makanan.

Pande Ketut Diah Kencana, M. (2015). Modul Pengemasan Pangan. Universitas Udayana, 1-10.

Fadlillah, H. N., Nuraida, L., \& Purnomo, E. H. (2015). Kepedulian Konsumen terhadap Label dan nformasi Bahan Tambahan Pangan (BTP) pada Label Kemasan Pangan di Kota Bogor. Jurnal Mutu Pangan: ndonesian Journal of Food Quality, 2(2), 119-126. https://journal.ipb.ac.id/index.php/jmpi/arti cle/view/27870

Jamrianti, R. (2021). Pengemasan dan Pelabelan Pangan: Packaging as a Product Cummunications. https://books.google.co.id/books?id=ligq EAAAQBAJ

Ningrum., A. . (2015). PENGETAHUAN LABEL KEMASAN PANGAN - Google Books. https://www.google.co.id/books/edition/P ENGETAHUAN_LABEL_KEMASAN_PA NGAN/ZX4qDwAAQBAJ?hl=en\&gbpv $=1$ $\& d q=$ pelabelan+pada+kemasan+pangan $\& p g=P A 1 \&$ printsec $=$ frontcover

http://istanaumkm.pom.go.id/regulasi/pangan/l abel 